\title{
Bioreactivity of peptidoglycan in seawater
}

\author{
Kiyo Kitayama ${ }^{1, *}$, Takeo Hama ${ }^{1}$, Katsumi Yanagi ${ }^{2}$ \\ ${ }^{1}$ Graduate School of Life and Environmental Sciences, University of Tsukuba, Tsukuba, Ibaraki 305-8572, Japan \\ ${ }^{2}$ Faculty of Engineering, Kyushu Sangyo University, Higashi-ku, Fukuoka 813-8503, Japan
}

\begin{abstract}
The components of bacterial peptidoglycan (PG), D-amino acids and muramic acid, have been identified as constituents of marine dissolved organic matter (DOM), suggesting that PG is a possible component of the recalcitrant DOM. However, little is known about the bioreactivity of PG directly released from bacterial cells. We conducted an incubation experiment on marine bacteria and examined the degradation processes of $\mathrm{PG}$ and protein released from bacterial cells using ${ }^{13} \mathrm{C}$ as a tracer. We used D-Ala for an indicator of PG, and L-Ala and L-Val for protein. Most PG released from bacterial cells degraded immediately, but a small portion remained at the end of the incubation experiment $(240 \mathrm{~d})$, accounting for $1.1 \%$ of maximum particulate PG in bacterial cells. Protein was more bioreactive than PG by one order of magnitude. The D:L ratio of Ala released from bacterial cells increased as the diagenetic stage progressed, indicating that this ratio is a useful indicator of bioavailability for dissolved organic compounds. The recalcitrant bulk organic carbon released from bacterial cells accounted for 1.8-4.8\% of the bacterial organic cellular carbon. Our results suggest that PG is more stable than protein, but more bioreactive than bulk dissolved organic carbon (DOC).
\end{abstract}

KEY WORDS: Dissolved organic matter · Peptidoglycan · Bacteria · Biological availability · Carbon 13 . Amino acid

Resale or republication not permitted without written consent of the publisher

\section{INTRODUCTION}

Marine dissolved organic matter (DOM) represents one of the largest reduced carbon reservoirs on earth. The amount of oceanic dissolved organic carbon (DOC) is estimated to be $685 \mathrm{PgC}$, making it comparable in abundance with atmospheric $\mathrm{CO}_{2}$ (Hansell \& Carlson 1998, Fasham et al. 2001). This quantitative comparability implies that marine DOM is fundamentally involved in the global carbon cycle. Our knowledge of marine DOM has accumulated remarkably over the last decade, including time and spatial variability, depth profiles, molecular weight composition, and microbial availability (Benner 2002). Estimations of the ${ }^{14} \mathrm{C}$ ages of DOM provide evidence that most DOM is resistant to microbial degradation (Williams \& Druffel 1987, Bauer et al. 1992). However, the chemical characteristics of refractory DOM (R-DOM) and the transformation processes from labile DOM to R-DOM are still poorly understood.
Heterotrophic bacteria are dominant consumers of marine DOM, and the possibility of their contribution to the marine carbon cycle as a producer of DOM has recently been proposed. Bacteria transform labile substrates to recalcitrant DOM that is resistant to further bacterial remineralization (Brophy \& Carlson 1989, Tranvik 1993, Heissenberger \& Herndl 1994, Stoderegger \& Herndl 1998, Ogawa et al. 2001). Furthermore, the dissolved organic compounds specific to bacteria have been reported to distribute ubiquitously in oceanic environments. Bacterial cell wall components such as membrane proteins (Tanoue et al. 1995, Yamada \& Tanoue 2003), lipopolysaccharides (Wakeham et al. 2003), and peptidoglycan (PG) (Lee \& Bada 1977, McCarthy et al. 1998, Dittmar et al. 2001, Benner \& Kaiser 2003, Pérez et al. 2003) have been found in marine DOM, indicating that such components are important constituents of R-DOM.

Peptidoglycan, a cell wall component, consists of strands of alternating $\beta$-1, 4-linked $N$-acetylgluco- 
samine and $N$-acetyl-muramic acid units, cross-linked by short peptides (Schleifer \& Kandler 1972). Amino acids in these peptides include D-enantiomers of Ala, Asp, Ser, and Glu, in contrast to cellular protein consisting of only L-amino acids. The occurrences of muramic acid and D-amino acids are known as typical features of PG and are used as molecular markers.

In marine DOM, 4 D-amino acids (Ala, Asp, Ser, and Glu) have been found ubiquitously, and the pattern of their D:L ratios of marine DOM is similar to that of PG (Lee \& Bada 1977, McCarthy et al. 1998, Dittmar et al. 2001, Pérez et al. 2003). Furthermore, muramic acid has been widely observed in marine DOM (Benner \& Kaiser 2003). Therefore, PG is likely to be resistant to microbial degradation and is a possible component of R-DOM.

In decomposition experiments on PG extracted from bacteria, however, PG is readily utilized by bacteria (Jørgensen et al. 2003, Nagata et al. 2003). One component of PG, muramic acid, was not detected in DOM after a lengthy incubation experiment (Ogawa et al. 2001). Thus, little direct evidence exists that PG released from bacterial cells survives as recalcitrant DOM, and the bioreactivity of PG is still a matter of controversy.

We quantitatively analysed the degradation processes of PG released from bacterial cells by an incubation experiment of marine bacterial populations. We labelled bacterially produced organic matter with ${ }^{13} \mathrm{C}$ and traced ${ }^{13} \mathrm{C}$-labelled $\mathrm{D}$-Ala as an indicator of $\mathrm{PG}$ using gas chromatography-mass spectrometry (GCMS). Furthermore, we compared the degradability of PG with that of protein (with L-amino acids as indicators) and bulk DOC derived from bacteria to elucidate the differences in bioreactivity among the components of bacterial cells.

\section{MATERIALS AND METHODS}

Incubation experiment. Artificial seawater was prepared according to Seki (1976). A solution of inorganic salts was prepared (compositional ratio: $\mathrm{NaCl}, 120.0 \mathrm{~g}$; $\mathrm{MgCl}_{2} \cdot 6 \mathrm{H}_{2} \mathrm{O}, 54.3 \mathrm{~g}_{;} \mathrm{Na}_{2} \mathrm{SO}_{4}, 20.0 \mathrm{~g} ; \mathrm{KCl}, 3.4 \mathrm{~g}_{;} \mathrm{H}_{2} \mathrm{O}$, $915.0 \mathrm{ml}$ ), to which $20 \% \mathrm{NaOH}$ was added until a faint precipitation occurred. To prepare 181 of the artificial seawater (salinity: 30\%o), $3.09 \mathrm{l}$ of the solution of inorganic salts was diluted with $14.91 \mathrm{l}$ of organic-free deionized water (Milli-Q, Millipore). Surface water was collected from Tokyo Bay, Japan on 1 March 2002 and filtered through a precombusted $\left(450^{\circ} \mathrm{C}, 5 \mathrm{~h}\right)$ glass fiber filter (GF/F, Whatman) immediately after the collection to remove phytoplankton and protists. The filtrate was used as an inoculum of the marine bacterial community.
The artificial seawater (18 l) was transferred to acidcleaned polycarbonate bottles (23 1) and inoculated with the natural bacterial community (2 l giving final concentration of $10 \% \mathrm{v} / \mathrm{v})$. After an addition of D-Glucose-U- ${ }^{13} \mathrm{C}_{6} \quad\left({ }^{13} \mathrm{C}, 98.9\right.$ atom\%; Chlorella Industry), $\mathrm{NaNO}_{3}$, and $\mathrm{Na}_{2} \mathrm{HPO}_{4}$ at final concentrations in the incubation medium of $13.9,2.8$, and $0.3 \mu \mathrm{M}$, respectively, the sample was incubated at $20^{\circ} \mathrm{C}$ in the dark for $240 \mathrm{~d}$. Subsamples (2 l) were collected at intervals of 1 to $30 \mathrm{~d}$ and passed through a $0.4 \mu \mathrm{m}$ pore-size filter (Nuclepore, Millipore) to separate them into particulate organic matter (POM) and DOM fractions. The filtrates were desalted by electrodialysis (Microacilizer S-3, Asahi Chemical) (Hama \& Yanagi 2001). The recovery of amino acids (free and combined forms) for electrodialysis was estimated to be $76.4 \pm 11.7 \%$ $(\mathrm{n}=4)$. Subsamples were concentrated to $20-30 \mathrm{ml}$ by a rotary evaporator and stored at $-20^{\circ} \mathrm{C}$ until analysis.

During the incubation experiment, organic matter produced by bacteria using ${ }^{13} \mathrm{C}$-glucose was labelled with ${ }^{13} \mathrm{C}$. The filtrate of the natural seawater, which was added as the bacterial inoculum, contained organic matter other than bacterial populations such as ambient DOM. Therefore, the sample contained 2 types of organic matter - that newly produced by bacteria during the incubation experiment and that already existing in the bacterial inoculum.

Analysis of D-Ala, L-Ala and L-Val. Particulate and dissolved amino acid hydrolysis was conducted with $6 \mathrm{~N} \mathrm{HCl}$ at $105^{\circ} \mathrm{C}$ for $12 \mathrm{~h}$ (Amelung \& Zhang 2001). Amino acids were purified by passage over a cation exchange resin (AG 50W-X8 Resin, Bio-Rad) and then derivatized to $N$-pentafluoropropionyl ( $N$-PFP) isopropyl esters. The concentration and ${ }^{13} \mathrm{C}$ atom\% of each amino acid were determined by GC-MS (Voyager, Thermo Electron). We used a capillary column (25 $\mathrm{m} \times 0.25 \mathrm{~mm}$ inside diameter [i.d.]) coated with Chirasil-L-Val (Chrompack, Varian) to separate amino acid enantiomers under the following conditions: car-

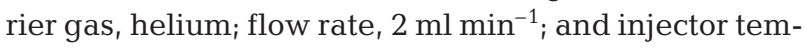
perature, $200^{\circ} \mathrm{C}$. The oven temperature was programmed as follows: the initial temperature of $50^{\circ} \mathrm{C}$ was increased to $80^{\circ} \mathrm{C}$ at $5^{\circ} \mathrm{C} \mathrm{min}^{-1}$ and held for $5 \mathrm{~min}$. Thereafter, the temperature was increased to $90^{\circ} \mathrm{C}$ at $1^{\circ} \mathrm{C} \mathrm{min}{ }^{-1}$, and finally to $190^{\circ} \mathrm{C}$ at $4^{\circ} \mathrm{C} \mathrm{min}{ }^{-1}$, and held for $5 \mathrm{~min}$. Electronic ionization (EI) method was applied, and the details of analytical conditions were as follows: electron energy, $70 \mathrm{eV}$; emission current, $350 \mu \mathrm{A}_{i}$ ion source temperature, $200^{\circ} \mathrm{C}_{i}$ and scan range, specific mass to charge ratio (m/z) 40-400. The concentration of amino acid and ${ }^{13} \mathrm{C}$ atom \% were precisely estimated when more than $50 \mathrm{ng}$ of each amino acid was injected.

The concentration of bacterial amino acids in the POM fraction was estimated using L-norvaline as an 
internal standard. The separation and quantitative analysis of L-norvaline were insufficient in the DOM fraction probably due to the possible effect of sea salt, although desalination was applied to the DOM fraction. Therefore, the concentration of bacterially produced amino acids in the DOM fraction was calculated using the concentration of amino acids in the bacterial inoculum that was added at the start of the incubation experiment. Details are shown in the 'Results' section.

Concentration of DOC. The concentrations of DOC during the incubation experiment were determined by high temperature catalytic oxidation with a Shimadzu TOC5000A analyser. Furthermore, ${ }^{13} \mathrm{C}$ atom \% of DOC on Day 240 was measured by a mass spectrometer with an elemental analyser (DELTAplus, Thermo Electron) (Hama \& Yanagi 2001) to estimate the concentration of ${ }^{13} \mathrm{C}-\mathrm{DOC}$.

Bacterial abundance. Subsamples were filtered onto a black polycarbonate filter $(0.2 \mu \mathrm{m}$ pore-size, Millipore), and the bacterial number on the filter was enumerated by epifluoroscence microscopy using 4'6diamidino-2-phenylindole (DAPI) (Porter \& Feig 1980).

\section{RESULTS}

\section{Bacterial abundance and DOC concentration}

Bacterial abundance rapidly increased from $0.6 \times 10^{5}$ cells $\mathrm{ml}^{-1}$ on Day 0 to $2.3 \times 10^{6}$ cells $\mathrm{ml}^{-1}$ on Day 1 (Fig. 1). Bacterial abundance was followed by a decline and on Day 10 was less than half of that on Day 1. Thereafter, it slowly diminished until Day 60 and remained low throughout the rest of the period.

The initial DOC concentration was $106 \mu \mathrm{MC}$ (Fig. 1), which was the sum of carbon derived from the added ${ }^{13} \mathrm{C}$-glucose $(83 \mu \mathrm{MC})$ and the filtrate of seawater as the bacterial inoculum $(23 \mu \mathrm{MC})$. The DOC concentration decreased considerably to $72 \mu \mathrm{MC}$ on Day 1 . After

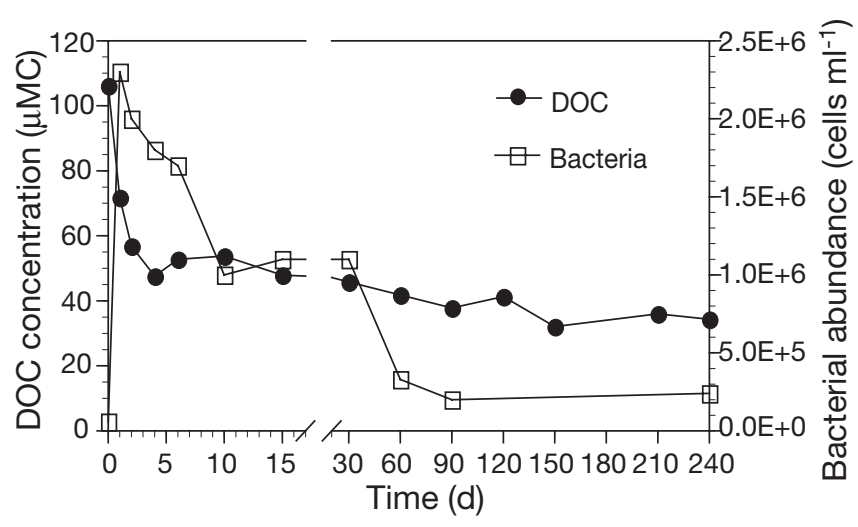

Fig. 1. Changes in DOC concentration and bacterial abundance during incubation experiment a rapid decrease during the initial $4 \mathrm{~d}$, the DOC concentration rate of decrease very slowly diminished, reaching $34 \mu \mathrm{MC}$ on Day 240. The ${ }^{13} \mathrm{C}$-DOC concentration was calculated by the bulk DOC concentration and its ${ }^{13} \mathrm{C}$ atom $\%$. Since the ${ }^{13} \mathrm{C}$ atom $\%$ of DOC on Day 240 was $4.55 \%$, the ${ }^{13} \mathrm{C}$-DOC concentration on Day 240 was estimated to be $1.2 \mu \mathrm{MC}$, which corresponded to $1.4 \%$ of the initially added glucose ${ }^{13} \mathrm{C}$.

\section{Estimation of bacterially produced Ala and Val (EI analysis)}

Mass spectra of $N$-PFP esters of amino acids by the EI analysis

The EI mass spectra of the $N$-PFP esters of L-Ala and L-Val in DOM of the incubated sample on Day 6 are shown in Fig. 2. The mass spectra of D-Ala were the same as those of L-Ala. The $N$-PFP ester of L-Ala was cleaved to generate some fragment ions, and significant peaks of m/z 190 and 192 were detected (Fig. 2a). The peak of $\mathrm{m} / \mathrm{z} 190$ corresponds to the fragment ion $\left(\mathrm{C}_{5} \mathrm{H}_{5} \mathrm{ONF}_{5}\right)$ which contains 2 carbons of the L-Ala molecule (Fig. 2b). Since it has no ${ }^{13} \mathrm{C}$ atom, this fragment ion was derived from L-Ala in the bacterial inoculum. The peak of $\mathrm{m} / \mathrm{z} 192$, which is heavier than $\mathrm{m} / \mathrm{z}$ 190 by 2 , is equivalent to the fragment ion which contains $2{ }^{13} \mathrm{C}$ atoms, and therefore is generated from bacterially produced L-Ala. In the case of the $N$-PFP ester of L-Val, peaks of m/z 218 and 222 were detected as the main peaks (Fig. 2c). The peak of m/z 218 is consistent with the fragment ion $\left(\mathrm{C}_{7} \mathrm{H}_{9} \mathrm{ONF}_{5}\right)$ which contains $4{ }^{12} \mathrm{C}$ atoms of the L-Val molecule (Fig. 2d), and is derived from $\mathrm{L}-\mathrm{Val}$ in the bacterial inoculum. The peak of $\mathrm{m} / \mathrm{z} 222$ corresponding to the fragment ion with $4{ }^{13} \mathrm{C}$ atoms is generated by bacterially produced L-Val.

\section{${ }^{13} \mathrm{C}$ atom $\%$ of amino acid}

The concentration and ${ }^{13} \mathrm{C}$ atom $\%$ of amino acid provided essential information to estimate the bacterially produced amino acids and were determined using GCMS. The ${ }^{13} \mathrm{C}$ atom $\%$ of each amino acid was calculated according to Kouchi (1982), using the relative intensities of m/z 190-192 for D and L-Ala and m/z 218-222 for $\mathrm{L}-\mathrm{Val}$. The incorporation of ${ }^{13} \mathrm{C}$ atom into the carbon of amino acid increases the relative intensities of the heavier isotopic peaks (Fig. 2: m/z 191 and 192 in Ala and $\mathrm{m} / \mathrm{z} 219-222$ in $\mathrm{Val})$. The ${ }^{13} \mathrm{C}$ atom $\%$ of each amino acid was calculated based on the increase in the relative intensities of the isotopic peaks and the number of $\mathrm{C}$ contained in each fragment according to the equation proposed by Kouchi (1982). 

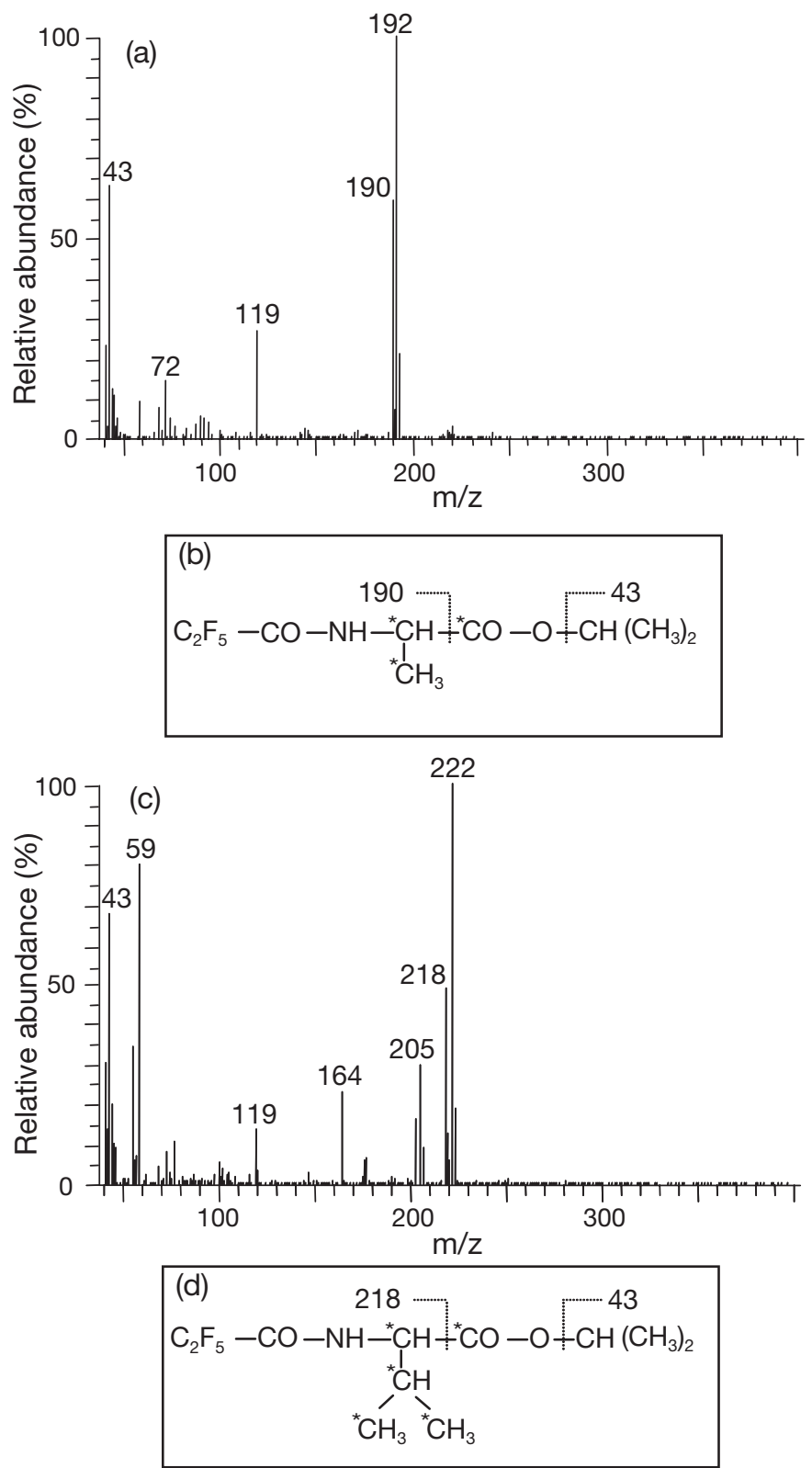

Fig. 2. Mass spectra and molecular structure of $N$-PFP esters of L-Ala and L-Val by electronic ionization method. Mass spectra of N-PFP esters of L-Ala (a) and L-Val (c) in DOM of the incubated sample on Day 6. Molecular structures of $N$ PFP esters of L-Ala (b) and L-Val (d) and their proposed ion fragmentation. Asterisks indicate carbons derived from Ala or Val molecule, and other carbons are those added by derivatization. $\mathrm{m} / \mathrm{z}$ indicates specific mass to charge ratio

Since the added glucose was labelled with ${ }^{13} \mathrm{C}\left({ }^{13} \mathrm{C}\right.$, 98.9 atom\%), bacteria used ${ }^{13} \mathrm{C}$ and little ${ }^{12} \mathrm{C}$ as carbon sources. Therefore, the ${ }^{13} \mathrm{C}$ atom $\%$ of amino acid was identical with the percentage of bacterially produced amino acid to total amino acid (bacterially produced and from bacterial inoculum) in the sample. Table 1 shows the ${ }^{13} \mathrm{C}$ atom $\%$ of amino acids in the POM and
DOM fractions. In the POM fraction, the ${ }^{13} \mathrm{C}$ atom $\%$ of amino acids increased rapidly, reaching ca. $90 \%$ on Day 1. This indicates that bacteria took up ${ }^{13} \mathrm{C}$-glucose and produced new amino acids immediately after the incubation was started. However, the ${ }^{13} \mathrm{C}$ atom \% of DAla, L-Ala, and L-Val in the DOM fraction reached their maxima on Day 6, and did not exceed 40,63, and $66 \%$, respectively. The ${ }^{13} \mathrm{C}$ atom $\%$ of amino acids in both POM and DOM fractions decreased toward the end of the incubation experiment.

Concentration of bacterially produced Ala and Val in POM fraction

In the POM fraction, the concentration of bacterially produced amino acid was calculated by multiplying the concentration of amino acid by its ${ }^{13} \mathrm{C}$ atom\% as follows:

$$
\begin{gathered}
\text { AA concentration } \text { produced }= \\
\text { AA concentration } \\
\text { sample } \\
\times{ }^{13} \mathrm{C} \text { atom } \%
\end{gathered}
$$

Table 1. The ${ }^{13} \mathrm{C}$ atom $\%$ of amino acids in POM and DOM fractions, and the ratios of ${ }^{13} \mathrm{C}$ to ${ }^{12} \mathrm{C}$ in DOM fraction (nd = not

\begin{tabular}{|c|c|c|c|c|}
\hline Amino acid & $\begin{array}{l}\text { Time } \\
\text { (d) }\end{array}$ & $\begin{array}{c}\text { POM } \\
{ }^{13} \mathrm{C} \text { atom } \%\end{array}$ & ${ }^{13} \mathrm{C}$ atom $\%$ & $\begin{array}{l}{ }^{\mathrm{M}} \mathrm{C}:{ }^{12} \mathrm{C} \\
\text {. }\end{array}$ \\
\hline \multirow[t]{10}{*}{ D-Ala } & 1 & 88.8 & nd & nd \\
\hline & 2 & nd & 26.4 & 0.36 \\
\hline & 4 & 81.1 & 30.9 & 0.45 \\
\hline & 6 & 75.6 & 38.2 & 0.62 \\
\hline & 10 & nd & 13.4 & 0.15 \\
\hline & 30 & 70.1 & 13.4 & 0.15 \\
\hline & 60 & 25.6 & 13.8 & 0.16 \\
\hline & 120 & 24.6 & 8.3 & 0.09 \\
\hline & 150 & 23.4 & 7.7 & 0.08 \\
\hline & 240 & 17.7 & 10.3 & 0.11 \\
\hline \multirow[t]{10}{*}{ L-Ala } & 1 & 91.4 & nd & nd \\
\hline & 2 & nd & 30.0 & 0.43 \\
\hline & 4 & 84.7 & 33.6 & 0.51 \\
\hline & 6 & 85.1 & 62.6 & 1.67 \\
\hline & 10 & nd & 23.7 & 0.31 \\
\hline & 30 & 81.6 & 19.0 & 0.23 \\
\hline & 60 & 39.6 & 12.4 & 0.14 \\
\hline & 120 & 33.9 & 7.3 & 0.08 \\
\hline & 150 & 36.8 & 6.5 & 0.07 \\
\hline & 240 & 31.2 & 8.4 & 0.09 \\
\hline \multirow[t]{10}{*}{ L-Val } & 1 & 90.9 & nd & nd \\
\hline & 2 & nd & 34.6 & 0.53 \\
\hline & 4 & 84.7 & 53.3 & 1.14 \\
\hline & 6 & 87.5 & 66.0 & 1.94 \\
\hline & 10 & nd & 39.3 & 0.65 \\
\hline & 30 & 84.4 & 22.5 & 0.29 \\
\hline & 60 & 44.4 & 14.8 & 0.17 \\
\hline & 120 & 38.0 & 8.2 & 0.09 \\
\hline & 150 & 30.1 & 8.2 & 0.09 \\
\hline & 240 & 33.3 & 9.2 & 0.10 \\
\hline
\end{tabular}
determined) 
The concentrations of amino acid denoted those newly produced during the experiment. The coefficients of variation used to determine concentrations of D-Ala, L-Ala, and L-Val in the POM fraction were $1.87-25.0 \%$ (mean $9.4 \%$ ), 3.57-41.3\% (mean 14.2\%), and 0.86$39.9 \%$ (mean $11.1 \%$ ), respectively $(\mathrm{n}=3)$.

The concentrations of particulate D-Ala, L-Ala, and LVal immediately increased, reaching their respective maxima of 14.4, 657, and $299 \mathrm{nM}$ on Day 1 (Fig. 3). The concentrations of L-amino acids were 21-46 times higher than that of D-Ala. The concentrations of these 3 amino acids decreased rapidly from Day 1 to 6 , and these decreases corresponded to ca. $30-40 \%$ of each maximum concentration on Day 1. Concentrations of these 3 amino acids continued to fall at diminishing rates until Day 60, and remained low throughout the incubation experiment. The concentrations of D-Ala, LAla, and L-Val on Day 240 were $0.4,25.8$, and $8.5 \mathrm{nM}$, respectively, which corresponded to $2.8,3.9$, and $2.8 \%$ of each concentration on Day 1, i.e. more than $95 \%$ of maximum concentrations of D-Ala, L-Ala, and L-Val decreased until Day 240, with no significant differences observed among these 3 amino acids. Temporal changes in the concentrations of amino acids in the POM fraction agreed with those in bacterial abundance, as shown in Fig. 1.

Concentration of bacterially produced Ala and Val in DOM fraction

For DOM samples, an insufficient separation of Lnorvaline (internal standard) made it difficult to mea-

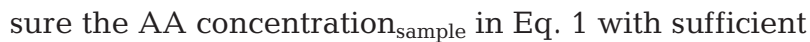
reliability, except for the samples obtained on Day 6 and Day 60. Thus, an alternative method was used for calculating AA concentration produced $_{\text {in }}$ the DOM fraction.

Amino acids produced by bacteria during the incubation experiment were labelled by ${ }^{13} \mathrm{C}\left({ }^{13} \mathrm{C}\right.$, 98.9 atom $\%$ ), whereas amino acids originally in the bacterial inoculum were mainly composed of ${ }^{12} \mathrm{C}\left({ }^{12} \mathrm{C}, 98.9\right.$ atom\%). Therefore, the ratio of $\mathrm{AA}_{\text {produced }}$ : $\mathrm{AA}_{\text {inoculum }}$ could be substituted with the ratio of ${ }^{13} \mathrm{C}:{ }^{12} \mathrm{C}$, as calculated in Table 1. We assumed that the AA concentration $_{\text {inoculum }}$ had remained constant throughout the incubation experiment. Therefore, the AA concentration $_{\text {produced }}$ was determined as follows:

$$
\begin{gathered}
\text { AA concentration } \\
\text { produced } \\
\text { AA concentration } \\
\text { inoculum } \times{ }^{13} \mathrm{C}:{ }^{12} \mathrm{C}
\end{gathered}
$$

Using Eq. 2 and the AA concentration ${ }_{\text {inoculum }}(\mathrm{D}-\mathrm{Ala}$, L-Ala, and L-Val were 1.42, 7.61, and $3.85 \mathrm{nM}$, respectively), the concentrations of bacterially produced D-Ala, L-Ala, and L-Val were estimated to be $0.88,12.7$,

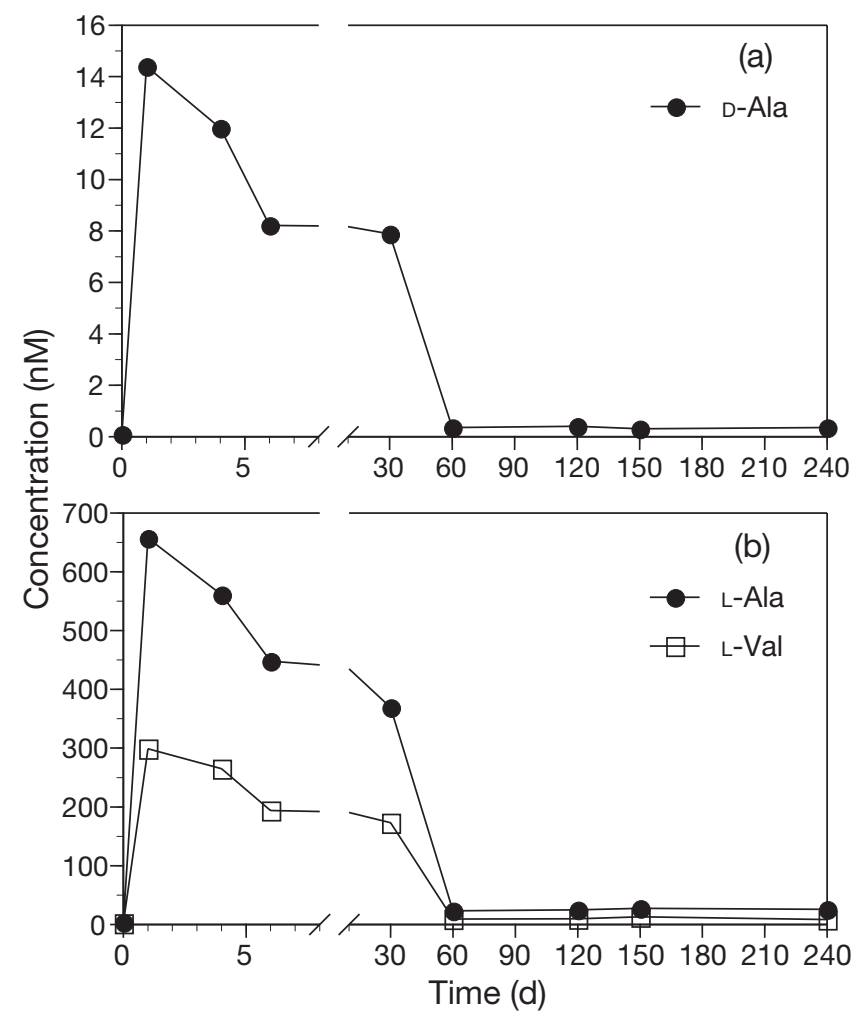

Fig. 3. Changes in concentrations of bacterially produced amino acids in POM fraction: (a) D-Ala, (b) L-Ala and L-Val

and $7.47 \mathrm{nM}$ on Day 6 , and $0.23,1.07$, and $0.65 \mathrm{nM}$ on Day 60, respectively. These concentrations were compared with those estimated by Eq. 1 (D-Ala, L-Ala, and L-Val were $0.76,15.7$, and $9.41 \mathrm{nM}$ on Day 6 and 0.15 , 1.50, and $0.89 \mathrm{nM}$ on Day 60, respectively), indicating no significant difference between either method. Thus, we used Eq. 2 for the calculation of the AA concentration $_{\text {produced }}$ in the DOM fraction. Analytical variations in the concentrations of D-Ala, L-Ala, and L-Val were $0.66-10.3 \%$ (mean $6.6 \%$ ), $0.67-2.88 \%$ (mean $1.7 \%$ ), and $0.33-6.48 \%$ (mean $1.6 \%$ ), respectively $(n=3)$.

Changes in the concentrations of amino acids in the DOM fraction are shown in Fig. 4. The concentrations of these 3 amino acids reached their maxima on Day 6 . The concentration of D-Ala decreased by $0.66 \mathrm{nM}$ from Day 6 to 10, which was equivalent to $75.0 \%$ of the dissolved D-Ala on Day 6. After Day 10, however, there was no significant decrease, and a minor portion of dissolved D-Ala remained until the end of the incubation experiment; the concentration of dissolved D-Ala on Day $240(0.16 \mathrm{nM})$ accounted for $18.2 \%$ of its maximum concentration on Day 6. The concentrations of LAla and L-Val also decreased rapidly from Days 6 to 10, and then continued to decrease slowly. The concentrations of the remaining L-Ala and L-Val on Day 240 were 


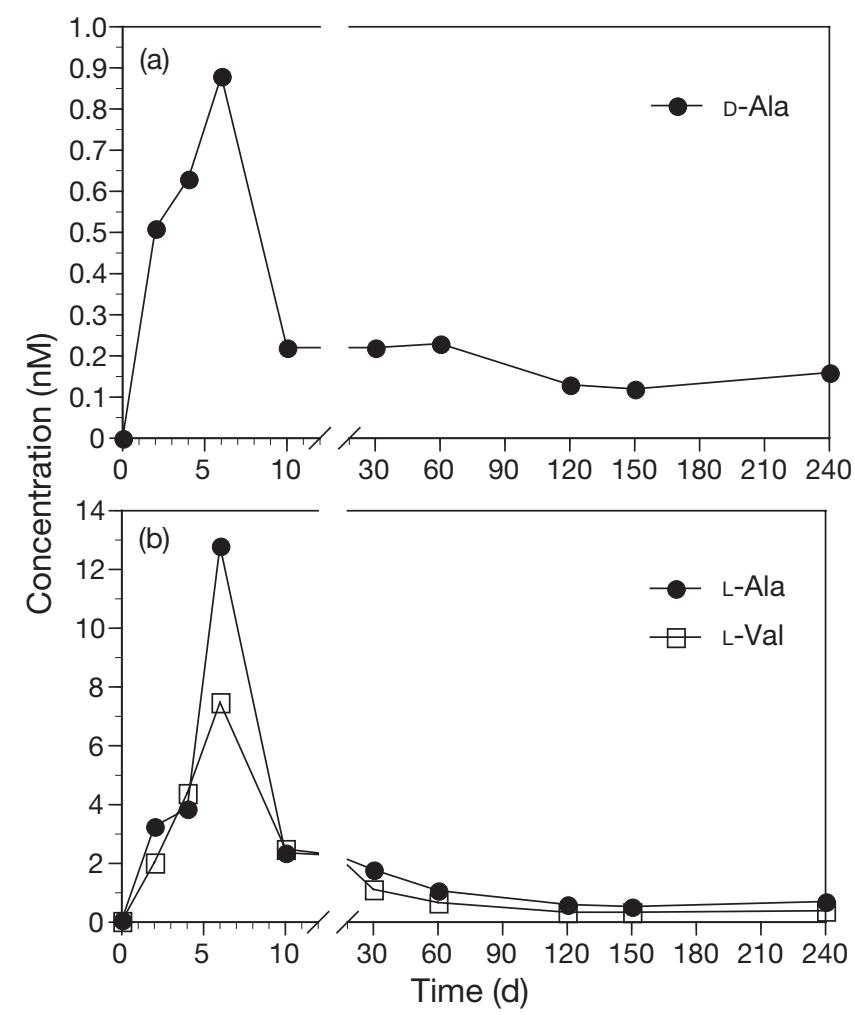

Fig. 4. Changes in concentrations of bacterially produced amino acids in DOM fraction: (a) D-Ala (b) L-Ala and L-Val

0.68 and $0.39 \mathrm{nM}$, respectively, which corresponded to 5.4 and $5.2 \%$ of each maximum concentration.

D:L ratio of bacterially produced Ala

The D:L ratio of Ala showed different temporal changes in the POM and DOM fractions (Fig. 5). The ratio in the POM fraction on Day 1 was 0.02 and showed no significant change throughout the incubation experiment. The DOM fraction, however, decreased at the beginning of the incubation experiment reaching a minimum of 0.07 on Day 6 . The D:L ratio ofAla increased significantly and reached 0.21 on Day 60, which indicates a selective utilization of L-Ala over D-Ala. The D:L ratio of Ala increased slightly after Day 60 and was at 0.24 on Day 240.

\section{DISCUSSION}

\section{Bioreactivity of PG released from bacterial cells}

Since the components of PG such as D-amino acids and muramic acid distribute widely throughout the marine water column (Lee \& Bada 1977, McCarthy et al. 1998, Dittmar et al. 2001, Benner \& Kaiser 2003, Pérez et al. 2003), PG has been considered to be one of the components of recalcitrant DOM. However, only a few studies have experimentally examined the bioavailability of PG (Jørgensen et al. 2003, Nagata et al. 2003). We quantitatively determined the release and degradation rates of PG from bacterial cells by measuring the ${ }^{13} \mathrm{C}$ labelled D-Ala, a useful marker of bacterial PG.

The concentration of particulate D-Ala reached a maximum on Day 1, whereas the maximum concentration of dissolved D-Ala did not reached until Day 6. The release of the components of the bacterial cells is caused by a viral infection and destruction of the cells (Fuhrman 1999), which is probably a major process in the production of dissolved D-Ala. Therefore, the increase observed in its concentration from Days 1 through 6 probably reflects the release of PG from bacterial cells and their accumulation in the culture medium. It is possible that the increase during the first day was partly due to the release of D-Ala as peptides accompanying the synthesis of new PG in the exponential growth phase (Goodell \& Schwarz 1985).

The accumulated D-Ala in DOM on Day 6 accounted for $6.1 \%$ of the maximum concentration of the particulate form, and corresponded to $14.2 \%$ of the difference in the concentration of particulate D-Ala between Days 1 and 6 , which indicates that most of the PG released from bacterial cells was immediately taken up by bacteria. The accumulated D-Ala in DOM, in turn, showed a rapid decrease in concentration from Days 6 to 10 . Thus, the increase in the concentration of dissolved DAla from Days 1 to 6 was only a temporary accumulation, corresponding to the difference between its production and consumption rates. These results suggest that bacterial PG exhibits a more bioreactive property than expected even though it has been found through-

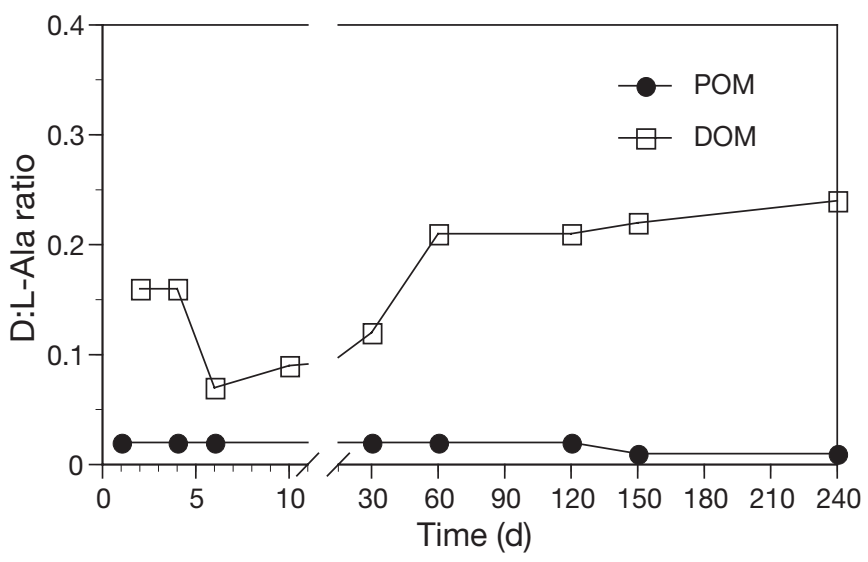

Fig. 5. Changes in the D:L ratios of bacterially produced Ala in POM and DOM fractions 
out the marine water column (Lee \& Bada 1977, McCarthy et al. 1998, Dittmar et al. 2001, Benner \& Kaiser 2003, Pérez et al. 2003). This indication is also supported by other experiments (Jørgensen et al. 2003, Nagata et al. 2003).

The concentration of dissolved D-Ala showed no decrease after Day 10. A certain amount of dissolved DAla was found even at the end of the experiment, corresponding to $18.2 \%$ of its maximum concentration. This, in turn, accounted for $1.1 \%$ of the maximum concentration of particulate D-Ala. Therefore, although most PG was used quickly after the release from bacterial cells, a small portion was resistant to microbial degradation and remained in dissolved form for a long time.

Since surface DOM is partly composed of labile and semi-labile DOM fractions (Ogura 1972, Cherrier et al. 1996), it is possible that some of the amino acid in the bacterial inoculum was decomposed during the incubation experiment. Therefore, the assumption that the

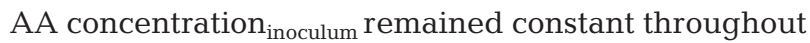
the experiment could result in an overestimation of the

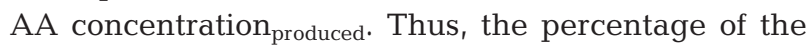
remaining $\mathrm{D}$-Ala to the maximum concentration of the particulate form would be considered as upper limit, as well as those of L-Ala and L-Val.

Muramic acid, as well as D-amino acids, has been used as a biomarker of bacterial PG. The bioreactivity of muramic acid is different from D-Ala; both high and low reactivity has been reported. Although muramic acid is typically found in equimolar yields with D-Ala in PG (Schleifer \& Kandler 1972), the yield of muramic acid in marine ultrafiltered DOM is more than 10-fold lower than that of D-Ala (Benner \& Kaiser 2003), suggesting that the peptide side chains of PG are more resistant than the glycan strand. On the other hand, the remineralization rate of the peptide component is 3fold higher than that of glycan moiety (Nagata et al. 2003). Thus, the proportion of the remaining PG estimated by the use of muramic acid as a biomarker may be different to that of D-Ala.

It is possible that the dissolved D-Ala was produced by archaea, since this group has peptidyl D-Ala (Nagata et al. 1998). The effect of archaea on the concentration of D-Ala could not be estimated quantitatively in the present study. However, the predominance of bacteria in surface seawater (DeLong 1992, Karner et al. 2001) suggests that they would be abundant in the bacterial inoculum. Furthermore, the D:LAla ratio of DOM on Day 240 was similar to that of the PG in bacteria (0.44-0.63; Amon et al. 2001, Grutters et al. 2002) rather than to that of protein containing D-Ala in archaea (0.004-0.067; Nagata et al. 1998). Therefore, we regard most dissolved D-Ala as being derived from PG in bacteria.

\section{Difference in bioreactivity between PG and protein}

Changes in the concentrations of L-Ala and L-Val can be regarded as those of protein, since they are major protein constituents. Temporal variations in the concentrations of dissolved L-Ala and L-Val were basically comparable with those of D-Ala, except for a difference observed in the degradability of L-amino acids from DAla. The concentrations of accumulated L-Ala and L-Val in DOM on Day 6 corresponded to only 1.9 and $2.5 \%$ of the maximum concentrations of particulate forms, respectively, which were considerably lower than that of D-Ala (6.1\%). Almost all the dissolved L-Ala and L-Val were utilized by bacteria during the subsequent incubation period, at the end of which the remaining concentrations accounted for only $0.1 \%$ of the maximum concentration of each particulate form. This ratio was lower than that of D-Ala by one order of magnitude. This finding clearly shows that protein is a more utilizable substrate for bacteria than PG. The remineralization rate of purified bacterial protein is 2-21 times higher than that of PG, as shown in a culture experiment (Nagata et al. 2003). In oceanic sediments, the proportion of D-amino acids increases with increasing depth, indicating the selective preservation of PG over protein (Pederson et al. 2001). Thus, it appears that the relative contribution of $\mathrm{PG}$ to organic matter increases with progressing diagenesis of organic matter.

\section{D:L ratio of Ala}

The increase in the D:L ratio of amino acid as the diagenetic stage progresses has been reported in culture experiments of algal-derived DOM (Amon et al. 2001) and surface seawater (Jørgensen et al. 1999). The D:L ratio of Ala released from bacterial cells also showed a significant temporal increase from 0.07 to 0.24 in the present study. The minimum D:L-Ala ratio was observed in the temporally accumulated DOM on Day 6, indicating that the fresh DOM had a low D:L-Ala ratio. The organic composition of fresh DOM probably reflects that of bacterial cells that contain a high level of protein relative to PG with the low D:L-Ala ratio of 0.02 . The dissolved D:L ratio of Ala significantly increased to 0.24 on Day 240 due to the selective utilization of L-Ala over D-Ala, indicating that DOM that has undergone microbial degradation exhibits a high D:L ratio of Ala. Thus, D:L amino acid ratios can be used as an indicator of the diagenetic stage of DOM, with high ratios indicating low DOM bioavailability. The D:L ratios of Ala from various marine DOM samples have been reported in the range of 0.28-0.69 (McCarthy et al. 1998, Pérez et al. 2003). Considering that these ratios were higher than that of the present study on 
Table 2. The percentages of remaining DOC to the initial substrate

\begin{tabular}{|lcccl|}
\hline Substrate & $\begin{array}{c}\text { Remaining } \\
\text { DOC }(\%)\end{array}$ & $\begin{array}{c}\text { Incubation } \\
\text { time }\end{array}$ & Property of DOC & Source \\
\hline${ }^{14}$ C-Glucose & 8.6 & $171 \mathrm{~h}$ & Capsular material & Stoderegger \& Herndl (1998) \\
${ }^{14}$ C-Glucose & 3 & $7 \mathrm{~d}$ & Humic substance & Tranvik (1993) \\
${ }^{14}$ C-Leucine & 6 & $8 \mathrm{~d}$ & $>50000 \mathrm{Da}$ & Heissenberger \& Herndl (1994) \\
${ }^{14}$ C-Glucose & 5 & $70-163 \mathrm{~d}$ & $700-1400 \mathrm{Da}$ & Brophy \& Carlson (1989) \\
${ }^{14}$ C-Leucine & 1.4 & $70-163 \mathrm{~d}$ & $700-1400 \mathrm{Da}$ & Ogaphy \& Carlson (1989) \\
Glucose & 5 & $>1 \mathrm{yr}$ & & Ogawa et al. (2001) \\
Glutamate & 7 & $>1 \mathrm{yr}$ & & This study \\
\hline${ }^{13}$ C-Glucose & 1.4 & $240 \mathrm{~d}$ & & \\
\hline
\end{tabular}

Day 240, the bulk of marine DOM is considered to pass through a prolonged diagenetic stage.

The D:L-Ala ratio in DOM was relatively high $(0.16)$ in the exponential growth phase. This would be caused by the release of D-Ala as a peptide accompanying the synthesis of new PG (Goodell \& Schwarz 1985) as discussed above. Therefore, the high D:L ratio of Ala in the exponential growth phase is unlikely to result from the difference of the degradability of D-Ala and L-Ala that was observed at the end of the experiment.

While the D:L ratio of Ala increased in the DOM fraction, it remained constant in the POM fraction throughout the incubation experiment. If protein is utilized selectively in POM as well as in DOM, the D:L-Ala ratio may be expected to increase as the extent of the decomposition progresses. The constancy of the D:LAla ratio in the POM fraction suggests that little difference in degradability exists between PG and protein in POM. In the ocean, the D:L-amino acid ratios in sediment traps were low (close to zero), indicating that Damino acids in the settling organic matter are not selectively preserved (Grutters et al. 2002). Thus, the mechanisms involved in the degradation of amino acid enantiomers are supposed to differ between particulate and dissolved forms.

It is possible that the racemization of amino acid is also induced by the hydrolysis and derivatization processes, so that we analysed the authentic L-amino acids with the same procedure used for the samples and estimated the D:L ratio of Ala to be $0.99 \times 10^{-3}$, which was lower than that reported by Kaiser and Benner (2005). Therefore, we concluded that the racemization due to analytical procedures had no significant effect on the D:L ratio of Ala of bacterial samples, and that the increase in the D:L ratio of Ala due to artificial racemization could be safely ignored.

\section{Bacterially produced recalcitrant DOM}

The conversion from labile to recalcitrant DOM through bacterial metabolism involves an important step in controlling the diagenetic processes of marine organic matter. In our study, ${ }^{13} \mathrm{C}-\mathrm{DOC}$, derived from bacterial cells, remained at the end of the experiment, accounting for $1.4 \%$ of the initially added ${ }^{13} \mathrm{C}$-glucose. The contribution of the remaining DOC to the initial substrate reportedly ranged from $1.4-8.6 \%$ (Table 2), though the incubation length and substrates used varied among the experiments. Thus, bacteria convert a small fraction of labile substrate to DOC that remains resistant to microbial degradation.

A few studies have been conducted on the bioreactivity of PG, and the bioavailability of PG has also been reported (Jørgensen et al. 2003, Nagata et al. 2003). However, the difference in bioreactivity between PG and bacterial bulk DOC remains unknown. Therefore, we estimated the percentage of the remaining bulk DOC at the end of the experiment to the organic carbon in bacterial cells. Since we did not directly measure the organic carbon in bacterial cells, we used the concentration of the initial ${ }^{13} \mathrm{C}$-glucose and the bacterial growth efficiency (BGE) reported so far. The BGE is the amount of new bacterial biomass produced per unit of organic carbon substrate assimilated, and has been reported in the range of $30-80 \%$ for incubation experiments using a simple organic substrate such as glucose or amino acid (del Giorgio \& Cole 2000). We multiplied the concentration of the initial ${ }^{13} \mathrm{C}$-glucose by BGE (30-80\%), and estimated the organic carbon in bacterial cells as 25-66 $\mu \mathrm{MC}$. Therefore, the concentration of ${ }^{13} \mathrm{C}$-DOC on Day $240(1.2 \mu \mathrm{MC})$ accounts for $1.8-4.8 \%$ of the organic carbon present in bacterial cells. We estimated that $1.1 \%$ of PG in bacterial cells remained in a dissolved form at the end of the experiment, which is lower than that of bulk DOC. Therefore, the bioreactivity of PG is lower than protein but higher than bulk DOC derived from bacterial cells. Thus, organic matter more recalcitrant than PG probably exists in bacterially-derived DOM. Further studies concerning the molecular structure of recalcitrant DOM and the bacterial transform efficiency will elucidate the key processes of the carbon flux towards the end products of the microbial metabolism driving carbon cycling in the marine water column. 
Acknowledgements. This research was financially supported by a grant from the Ministry of Education, Culture, Sports, Science, and Technology, Japan (14340166 and 15510013) and a Sasakawa Scientific Research Grant from The Japan Science Society (14-370M).

\section{LITERATURE CITED}

Amelung W, Zhang X (2001) Determination of amino acid enantiomers in soils. Soil Biol Biochem 33:553-562

Amon RMW, Fitznar H-P, Benner R (2001) Linkages among the bioreactivity, chemical composition, and diagenetic state of marine dissolved organic matter. Limnol Oceanogr 46:287-297

Bauer JE, Williams PM, Druffel ERM (1992) ${ }^{14}$ C activity of dissolved organic carbon fractions in the north-central Pacific and Sargasso Sea. Nature 357:667-670

Benner R (2002) Chemical composition and reactivity. In: Hansell DA, Carlson CA (eds) Biogeochemistry of marine dissolved organic matter. Academic Press, San Diego, CA, p 59-90

Benner R, Kaiser K (2003) Abundance of amino sugars and peptidoglycan in marine particulate and dissolved organic matter. Limnol Oceanogr 48:118-128

Brophy JE, Carlson DJ (1989) Production of biologically refractory dissolved organic carbon by natural seawater microbial populations. Deep-Sea Res 36:497-507

Cherrier J, Bauer JE, Druffel ERM (1996) Utilization and turnover of labile dissolved organic matter by bacterial heterotrophs in eastern North Pacific surface waters. Mar Ecol Prog Ser 139:267-279

del Giorgio PA, Cole JJ (2000) Bacterial energetics and growth efficiency. In: Kirchman DL (ed) Microbial ecology of the oceans. Wiley-Liss, New York, p 289-325

DeLong EF (1992) Archaea in coastal marine environments. Proc Natl Acad Sci USA 89:5685-5689

Dittmar T, Fitznar HP, Kattner G (2001) Origin and biogeochemical cycling of organic nitrogen in the eastern Arctic Ocean as evident from D- and L-amino acids. Geochim Cosmochim Acta 65:4103-4114

Fasham MJR, Baliño BM, Bowles MC (eds) (2001) A new vision of ocean biogeochemistry after a decade of the Joint Global Ocean Flux Study (JGOFS). Ambio Spec Rep 10

Fuhrman JA (1999) Marine viruses and their biogeochemical and ecological effects. Nature 399:541-548

Goodell EW, Schwarz U (1985) Release of cell wall peptides into culture medium by exponentially growing Escherichia coli. J Bacteriol 162:391-397

Grutters M, Raaphorst WV, Epping E, Helder W, de Leeuw JW (2002) Preservation of amino acids from in situproduced bacterial cell wall peptidoglycans in northeastern Atlantic continental margin sediments. Limnol Oceanogr 47:1521-1524

Hama T, Yanagi K (2001) Production and neutral aldose composition of dissolved carbohydrates excreted by natural marine phytoplankton populations. Limnol Oceanogr 46: 1945-1955

Hansell DA, Carlson CA (1998) Deep-ocean gradients in the concentration of dissolved organic carbon. Nature 395: 263-266

Heissenberger A, Herndl GJ (1994) Formation of high molecular weight material by free-living marine bacteria. Mar Ecol Prog Ser 111:129-135

Jørgensen NOG, Tranvik LJ, Berg GM (1999) Occurrence and bacterial cycling of dissolved nitrogen in the Gulf of Riga, the Baltic Sea. Mar Ecol Prog Ser 191:1-18

Jørgensen NOG, Stepanaukas R, Pedersen A-GU, Hansen M, Nybroe O (2003) Occurrence and degradation of peptidoglycan in aquatic environments. FEMS Microbiol Ecol 46: 269-280

Kaiser K, Benner R (2005) Hydrolysis-induced racemization of amino acids. Limnol Oceanogr Methods 3:318-325

Karner MB, DeLong EF, Karl DM (2001) Archaeal dominance in the mesopelagic zone of the Pacific Ocean. Nature 409: $507-510$

Kouchi H (1982) Direct analysis of ${ }^{13} \mathrm{C}$ abundance in plant carbohydrates by gas chromatography-mass spectrometry. J Chromatogr 241:305-323

Lee C, Bada JL (1977) Dissolved amino acids in the equatorial Pacific, the Sargasso Sea, and Biscayne Bay. Limnol Oceanogr 22:502-510

McCarthy MD, Hedges JI, Benner R (1998) Major bacterial contribution to marine dissolved organic nitrogen. Science 281:231-234

Nagata T, Meon B, Kirchman DL (2003) Microbial degradation of peptidoglycan in seawater. Limnol Oceanogr 48: 745-754

Nagata Y, Fujiwara T, Kawaguchi-Nagata K, Fukumori Y, Yamanaka T (1998) Occurrence of peptidyl D-amino acids in soluble fractions of several eubacteria, archaea and eukaryotes. Biochim Biophys Acta 1379:76-82

Ogawa H, Amagai Y, Koike I, Kaiser K, Benner R (2001) Production of refractory dissolved organic matter by bacteria. Science 292:917-920

Ogura N (1972) Rate and extent of decomposition of dissolved organic matter in surface seawater. Mar Biol 13:89-93

Pedersen A-GU, Thomsen TR, Lomstein BAa, Jørgensen NOG (2001) Bacterial influence on amino acid enantiomerization in a coastal marine sediment. Limnol Oceanogr 46:1358-1369

Pérez MT, Pausz C, Herndl GJ (2003) Major shift in bacterioplankton utilization of enantiomeric amino acids between surface waters and the ocean's interior. Limnol Oceanogr 48:755-763

Porter KG, Feig YS (1980) The use of DAPI for identifying and counting aquatic microflora. Limnol Oceanogr 25:943-948

Schleifer KH, Kandler O (1972) Peptidoglycan types of bacterial cell walls and their taxonomic implications. Bacteriol Rev 36:407-477

Seki F (1976) The methods in aquatic microbial ecology. Kyoritsu Shuppan, Tokyo (in Japanese)

Stoderegger K, Herndl GJ (1998) Production and release of bacterial capsular material and its subsequent utilization by marine bacterioplankton. Limnol Oceanogr 43:877-884

Tanoue E, Nishiyama S, Kamo M, Tsugita A (1995) Bacterial membranes: possible source of a major dissolved protein in seawater. Geochim Cosmochim Acta 59:2643-2648

Tranvik LJ (1993) Microbial transformation of labile dissolved organic matter into humic-like matter in seawater. FEMS Microbiol Ecol 12:177-183

Wakeham SG, Pease TK, Benner R (2003) Hydroxy fatty acids in marine dissolved organic matter as indicators of bacterial membrane material. Org Geochem 34:857-868

Williams PM, Druffel ERM (1987) Radiocarbon in dissolved organic matter in the central North Pacific Ocean. Nature 330:246-248

Yamada N, Tanoue E (2003) Detection and partial characterization of dissolved glycoproteins in oceanic waters. Limnol Oceanogr 48:1037-1048 